\title{
Challenging Disney Myths ${ }^{1}$
}

\author{
Janet Wasko² \\ University of Oregon
}

\begin{abstract}
The article draws on recent studies of the Walt Disney Company that have utilized a variety of theoretical and methodological approaches to challenge some of the myths that surround the company, its products, and its creator, Walt Disney. The discussion considers five assumptions that are typically made about Disney: 1. Walt Disney was a creative genius who was responsible for the company's success; 2. The Disney company is somehow special and unique, not like other corporations; 3. Disney is only for kids; 4. Disney's products are harmless, safe and unbiased; and, 5. Everyone adores Disney. The arguments that challenge these myths are drawn from a wide range of studies from different disciplines, but rely heavily on the integration of political economy, critical cultural analysis and reception research.
\end{abstract}

Key words: Walt Disney, myths, deconstruction, multiple methodology.

\footnotetext{
${ }^{1}$ Este artigo retoma reflexões efetuadas no artigo "Challenging Disney Myths", publicado no Journal of Communication Inquiry, Vol. 25, No. 3, Julho 2001, 237-257.

2 Janet Wasko is Ph.D. University of Illinois and Professor at the School of Journalism and Communication, University of Oregon. Author of Movies \& Money: Financing the American Film Industry (Ablex,1982); Hollywood in the Information Age (Polity Press, 1995); and Understanding Disney: The Manufacture of Fantasy (Polity Press, 2001). She is a co-editor of nine other volumes on issues relating to political economy of communications and democratic communications.
} 
Resumo: Este artigo tem como base estudos recentes a respeito da Walt Disney Company que utilizaram uma variedade de estratégias teóricas e metodológicas para questionar alguns mitos que rodeiam esta companhia, seus produtos e seu criador, Walt Disney. A discussão considera cinco premissas que são tipicamente feitas sobre a Disney: 1. Walt Disney era um gênio criativo que foi responsável pelo sucesso da companhia; 2. A Disney Company é, de alguma maneira especial e única, diferente de outras corporações; 3. A Disney é somente para crianças; 4. Os produtos da Disney são inofensivos, seguros e não tendenciosos; e, 5. Todos adoram a Disney. Os argumentos que desmontam estes mitos são baseados em uma variedade de estudos de diferentes disciplinas, mas que se apóiam fortemente na integração da economia política, análise crítica da cultura e pesquisa de recepção.

Palavras-chave: Walt Disney, mitos, desconstrução, metodologia múltipla.

One of the contributions of critical political economy in communications studies has been to challenge some of the myths and assumptions associated with the development of media and communication systems. For instance, the notion that media and information have developed not purely as forms of public service or art, but also as commodities and industries, has been one of the cornerstones of a critical political economic analysis. Other fundamental assumptions have been critiqued, including the notion of a "free" marketplace, various misconceptions about competition, the relationship between capitalism and democracy, and especially issues relating to the "free flow" of information. 
Political economists continue to challenge these and other myths, but are able to do a much better job when incorporating insights from critical cultural analysis and reception studies. While other political economists have argued persuasively for the need to integrate approaches (Mosco, 1996; Meehan, 1986), this article will draw on recent studies of the Walt Disney Company that have utilized a variety of theoretical and methodological approaches to challenge some of the myths that surround the company, its products, and its creator, Walt Disney. ${ }^{3}$

Of course, the Disney company traditionally has relied on myths and fairy tales for its classic animated features. But another set of myths based on widespread assumptions about the company and its founder seems to protect Disney from critical scrutiny by the general public, as well as by scholars who have studied the company's cultural products. The discussion that follows considers five assumptions that are typically made about Disney: 1. Walt Disney was a creative genius who was responsible for the company's success; 2. The Disney company is somehow special and unique, not like other corporations; 3. Disney is only for kids; 4. Disney's products are harmless, safe and unbiased; and, 5. Everyone adores Disney. The arguments made to question these myths are drawn from a wide range of studies from different disciplines, but rely heavily on the integration of political economy, critical cultural analysis and reception research.

\section{Myth \#1: Walt Disney, the creative genius}

In the truest American Tradition, Walt Disney rose from virtual obscurity to become, through his beloved character creations, filmland's greatest success. . by virtue of his unsurpassed imagination, native genius, determination, and resourcefulness, he has utilized all so effectively as to become a world renowned, self-made pioneer in creating highly entertaining, thoroughly delightful, colorful, and educative motion picture spectacles. (cited in Watts, 1997, p. 58)

The most pervasive myths associated with the Disney company probably have to do with Walt Disney himself. To establish a foundation for understanding the Disney phenomenon, it is necessary to sort through the many biographies, hagiographies and

\footnotetext{
${ }^{3}$ The discussion is based on Wasko (2001), and Wasko, Phillips and Meehan (2001). 
accounts of Disney's life that rely heavily on a great man approach to history. Disney obviously owned and clearly controlled the company during his life, as well as playing a very strong leadership role in the company's management for most of that time. Thus, it is sometimes difficult to separate the history of Disney, the man, from the history of Disney, the company. Nevertheless, understanding both of these Disney histories is essential.

It also is necessary to establish the cultural and social context in which Disney and his company developed. In this sense, it is crucial to study Disney through the interweaving of historical and cultural critiques, as well as instrumental and structural analysis. In brief, instrumental approaches have been used to understand corporations by focussing on individuals, while structural analysis considers corporate activities within the context of more general economic and political contexts. As Murdock (1982) has argued, to understand the full dynamics of media corporations, it is essential to develop both instrumental and structural analysis, examining "the complex interplay between intentional action and structural constraint at every level of the production process." (p. 125)

Great Man History. From the early 1930s until his death in 1966, Disney received an enormous amount of public attention - probably more than the movie moguls who distributed his cartoons. But the fascination has continued with numerous biographies appearing since his death, as well as the more expected glorification by the Disney corporation itself. As McReynolds (1971) observed, there is a "...pseudo-religious aura which has come to surround his name before and since his death."

Much of the story was deliberately constructed by Walt Disney himself and carefully repeated over the years by Disney, his family and the Disney company. ${ }^{4}$ Watts (1997) reported that close acquaintances said that Disney was "preoccupied" by his own history, and that it is clear that "Disney mythologized his past and presented it to the public" (p. 7). Meanwhile, Schickel (1968) concluded that "Walt Disney's greatest creation was Walt Disney." Taxel (1982) echoed these sentiments: "His success in building an

\footnotetext{
${ }^{4}$ One of the most commonly cited sources in Disney biographies is Miller (1956), Disney's daughter.
} 
empire based on the animated film and in making his name one of the best known in the world was, to most, far more intriguing than any of the products he created."

It may not be surprising that the story of Walt Disney seems to have special, almost sacred, meaning for Americans. Not only does the Disney company actively present him in this special, sacred way, but the legends of Walt and Mickey Mouse have been picked up and repeated endlessly by journalists historians and biographers. ${ }^{5}$ Even the more critically-oriented biographies often attempt to psychoanalyze the man through the Disney products, and inevitably conclude with consummate praise for Disney's genius.

Not only does this perpetuate the "great man" version of history, this on-going fascination with Disney and his accomplishments tends to reinforce individualist assumptions, plus deflect attention away from the corporate nature of his enterprise. For example, Leonard Maltin (1973), one of Disney's well-known chroniclers, asks: "...why and how did Walt Disney get to the top of the heap and stay there? Most of the answers are to be found in the man himself."

The Walt Disney myth can be challenged in the following ways, which will be discussed in more detail: 1 . inaccurate facts about his life; 2. misconceptions about his character; 3. distortions of his abilities; and, 4. lack of attention to specific characteristics and roles.

Walt's Life. Information that is included in some of the versions of Walt Disney's story is simply incorrect or highly exaggerated. For instance, Disney's memories of small town life were said to provide the context for many of the themes in Disney productions, as well as the primary source of inspiration for Main Streets at the Disney parks. While struggling to gain financial security, the Disney family moved from Chicago to a farm in Missouri (1906), to Kansas City (1910), and then back to Chicago (1917). Later in his life,

\footnotetext{
${ }^{5}$ Among the most frequently cited biographies are Schickel (1976), Mosley (1985), Greene and Greene (1991) and Eliot (1993). More recently, Watts (199??) presented a relatively thorough discussion of Disney, relying on primary sources from the Disney Archives. Jackson (1993) included a biography, a biographical essay, and "Key Disney Sources," and explained that "an exhaustive treatment of Disney resources is not possible nor even desirable by virtue of the fact that much of it is inaccurate..."
} 
Disney often referred to his memories of the farm and rural life in Marceline, Missouri. The irony pointed out by some biographers is that the family lived in Marceline only a few years, thus Disney's rural roots were relatively shallow. Nevertheless, Disney "idealized and romanticized" these memories, which provided the basis for his attachment to small-town America and its values.

When the family moved to Kansas City, Walt and his older brother, Roy, apparently suffered from long hours of hard work for their father's new business, but also were reportedly subjected to some physical abuse. Roy served as an ally and protector of the younger Walt, but upon reaching maturity, left the family as two other older brothers had done previously. Thus, despite his fondness for warm and happy families, Walt Disney's own family life lacked these attributes.

Another well known part of the Disney legend is the creation of Mickey Mouse. The most famous version features Disney and his wife travelling by train from New York after learning that the company's popular character, Oswald, the Rabbit, had been lost to the company's distributor in New York. Disney creates Mickey, at first called Mortimer, and returns to Hollywood with the first cartoon in mind. This story is repeated quite often in accounts of Disney's life.

Another version claims that Walt and his chief animator, Ub Iwerks, designed Mickey at their studio in Los Angeles after the loss of Oswald. The more careful biographies agree that the creation of The Mouse was a collaboration between Disney and Iwerks, however, Disney most often took the credit. What is indisputable is that Mickey Mouse was an instant success, not only with distributors and theater owners, but with the public. In his controversial biography of Disney, Eliot (1993) notes that there were more sophisticated animated shorts being made at the time. "However, what set Disney's films apart was his ability to produce cartoons that not only talked but made lots of money, and that combination made them highly desirable to the industry's leading distributors." (p. 49)

In reading many of the accounts of Disney's life, one would think that Walt singlehandedly created the company as well as its innovative characters (such as Mickey) and other products. However, it is a mistake to focus attention only on Walt as the creative 
genius behind the Disney phenomenon. As noted previously, Walt was a major force in the studio's development, however, he was not the only one responsible for the success of the company's films. Commercial filmmaking, in general, and especially animation, is a collective art form. As simply explained in a "behind-the-scenes" book published (ironically) by Disney, "Animation is a team sport. Yes, there are leaders and followers, but for the most part, an animated film is created by a team of very creative people." (Hahn, 1996, p. 12) While Walt was the guiding force at the studio in the early years, Roy Disney also contributed greatly to the company's success, as did many others at the studio. In other words, Walt relied on other artists and managers to accomplish the studio's work and to create "Disney art."

Walt's Character. To the public, the image of Walt Disney grew to become one of a kindhearted, gentle individual, personified by his nickname, "Uncle Walt." He was praised as well for his masterful and inspirational leadership, as well as for being the consummate family man.

In one of the more insightful discussions of Disney, Bryman (1995) describes Walt as one of those rare charismatic leaders, "who dream up a vision about the need for a product, attract others to that vision and build the organization into an enthusiastic group of adherents." (p. 14) In other biographies, he is characterized as extremely ambitious, with a perpetual positive attitude and a strong belief in hard work and high quality products.

But even the most laudatory biographies also point out that Disney was authoritative, moody, and demanding. Some of his employees called him a benevolent dictator and reported various scare tactics he used to get his way. The more critical histories reveal that "Uncle Walt" was extremely controlling and obsessive. ${ }^{6}$ It is well known many of the early films produced by the studio only carried Disney's name, with no credit given for the many artists and workers who helped create the products.

\footnotetext{
${ }^{6}$ Personal attributes discussed by Eliot (1993), including impotence, alcoholism, nervous ticks, and compulsive cleanliness, make it easy to understand why the Disney family publicly decried the release of Eliot's book.
} 
There is no doubt, however, that Disney's attributes included a "remarkable capacity to sell his product and himself." (Watts, 1997, p. 46) He was especially adept at projecting his own image as someone who had become successful through hard work and perseverance. The press picked up his story and ran with it, repeating endlessly the saga of "the Horatio Alger of the cinema" and the self-made-man image that Disney cultivated. By 1934, Fortune observed that "Enough has been written about Disney's life and hard times already to stamp the bald, Algeresque outlines of his career as familiarly on the minds of many Americans as the career of Henry Ford or Abraham Lincoln." (Fortune, 1934)

As for his image as a family man, the more critical biographies note that Disney's work often took precedence over his family. And, while this would be insignificant for most people's professional lives, the connection typically made between his family life and the nature of his work, call for a more careful assessment.

Walt's Abilities. Walt Disney is often praised as an artistic and technological genius, as well as an innovative educator. Throughout the 1930s and 40s, a host of art critics sung the praises of "Disney, the Artist," comparing him to da Vinci, Michelangelo, Brueghel, Rembrandt and Picasso, among other famous artists. (See Low, 1942; Grafly, 1933) The academic world joined the art world with exhibitions and honorary degrees awarded to Walt Disney from Harvard, Yale and the University of Southern California.

In spite of his image as a talented artist, Disney actually did little drawing after 1924 when he started working with Ub Iwerks. ${ }^{7}$ Disney was reported to have been more than a bit frustrated when asked to sign autographs, as he struggled to duplicate the famous Disney signature that the public came to recognize and expect. However, most accounts agree that Disney's talent was in story-editing or development, with a innate sense of what would entertain the public and the ability to communicate these ideas to his staff.

It is often implied that Disney also was a technological wizard who was responsible for everything from animation itself and various advances in animation, including sound and color animation, the multiplane camera, feature-length animation, etc. Again, Walt had

\footnotetext{
${ }^{7}$ There are numerous sources for this point, including Schickel and Watts.
} 
some part in some of these innovations, but others at the Disney studio as well as other animation studios deserve credit, as well.

Another part of Disney's reputation was as an educator. This was especially emphasized after the introduction of several documentary series beginning in the 1960s. The films not only received the approval of the film industry through numerous Academy Awards, but also built Walt Disney's reputation as a documentarian and educator, for which he received many prestigious awards. However, despite all the praise and adulation, Disney himself denied the educational significance of the company's productions, explaining at one point, "I'm not an educator. My primary purpose is to entertain though if people want to read education into my work, that's fine with me." (Jackson, 1993, p. 81)

The Unknown Walt. Certain aspects of Disney's life have been consistently under-emphasized or simply left out of most accounts. For instance, based on some of the discussions of his life, Uncle Walt would appear to have been somewhat apolitical and only interested in entertaining people. However, as labor troubles surfaced at the Disney studio in the 1940s, so did Walt's conservative politics. During the depression, he adhered to a type of populism that distrusted bankers and the monopolistic practices of big business. But increasingly, he moved from a sentimental to a more paranoid version of populism, becoming vehemently anti-communist. As Watts (1997) explained, he had become "a conservative Republican whose intense patriotism, loyalty to the work ethic, suspicion of regulatory government, and support for American individualism had grown steadily more intense." (p. 441)

A lesser known chapter of Walt Disney's legacy is his role in the formation of the Motion Picture Alliance for the Preservation of American Ideals (MPA), the organization that set the foundation for the Hollywood blacklist. Disney served as the MPA's First Vice President and was prominently featured in publicity about the organization. The MPA has been acknowledged as the inspiration for the House Un-American Activities Committee (HUAC) investigation of Hollywood, which examined film industry notables on their adherence to the Smith Act, which made support of certain political parties illegal. 
Disney testified at the second set of HUAC hearings in 1947, along with other friendly witnesses (including Ronald Reagan), explaining that the strike at his studio had been organized by communists, and "throughout the world all of the Commie groups began smear campaigns against me and my pictures." He also stated that communism was "an un-American thing" and had infiltrated labor groups, especially. The well-known Hollywood blacklist had already been established, but Disney's testimony was said to have strengthened it. ${ }^{8}$ Meanwhile, the MPA served as the bastion of anti-communism in Hollywood through the 1950s, a period in which hundreds of Hollywood workers lost their industry jobs.

Another aspect of his life that is neglected by most of his biographers is his collaboration with the FBI from at least the 1950s through the end of his life.' Disney's FBI file includes a 1954 memo offering the agency "complete access to the facilities of Disneyland for use in connection with official matters and for recreational purposes." The file also includes evidence that Disney was a Special Correspondent for the agency. Whether or not Disney actively assisted the FBI, his well-documented cooperation with the agency clearly establishes his strong conservative credentials.

Another aspect of Disney's life that has been overlooked is his role as a capitalist. As Bryman (1997) suggests, there was some "ambiguity about Walt's status as a businessman." For instance, in most accounts, the company's extensive merchandising activities were typically ignored. Nevertheless, there is considerable evidence that Walt Disney was interested and involved in the business side of the company, and not merely in artistic or other kinds of success. Disney once advised: "Don't create potboilers. Create masterpieces. There's such a big market for masterpieces." (Stillwell, 1938, p. 8) In 1953, over the objections of his brother, Roy, he had set up a company to control the rights to his name. Retlaw - Walter spelled backwards) — received 5\% of the income received by

${ }^{8}$ See "The Testimony of Walter E. Disney Before the House Committee on UnAmerican Activities," in Peary and Peary (1980).

${ }^{9}$ Watts, (1997, p. 349) claims it was the 1950s; Eliot (1993) says that it was the early 1940s. 
the company from merchandising, and by the 1960s, was drawing around $\$ 500,000$ each year. (Grover, 1991, p. 10) Disney died a rich man.

Genius on Ice? Jackson (1993) observed in her biographical bibliography: "Walt Disney, the man, may be gone. However, the myth he created remains very much alive." As noted previously, many of the myths have been perpetuated through biographies that accept the Disney legacy without question. Given the on-going predilection for "great man history," as well as the growing fascination with celebrity biographies, the pseudo-religious profiles of Walt Disney will probably continue. As Bryman (1997) concluded, "...'Walt Disney' is also in a sense a social construction - a product of his own and others' efforts at creating a public face and a personal biography that would serve his business's aims."(p. 33) In other words, the Walt Disney myth benefits the company and will continue to be promoted as such.

Indeed, the company's website now includes the "Walt Disney Family Museum," which includes "Walt's Story," "Walt's Thoughts," a "Family Album," film clips, a "Walt Disney Dictionary," more detailed biographical material by historians Katherine and Richard Greene, and other special features. The site is produced by the Walt Disney Family Foundation, a non-profit organization which was founded in 1995 " to promote and produce serious discussion, writing, and scholarship about the life, work, and philosophy of Walt Disney." ${ }^{10}$ A video of Walt's life is planned for the future, and, of course, there is also an on-line gift shop, where various Disney biographies and other books can be purchased.

There is a fairly widespread rumor that Walt's body is on ice somewhere, waiting to be revived cryogenically when medical science will be able to heal his fatal affliction. ${ }^{11}$ Whether or not this myth is true (it's probably not), it is less important than some of the other myths mentioned above that continue to influence the public's perception of Disney.

\footnotetext{
${ }^{10}$ http://disney.go.com/disneyatoz/waltdisney/home.html,

11 This is one of the most common myths (or urban legends) about Disney, even internationally. Many authors discuss Disney's interest in cryogenics before his death, including Bryman, Thomas, and Fjellman.
} 
Using political economic, historical and cultural analysis, it is possible to dispute some of the Walt Disney myths, and thus challenge the glorification of individualism by understanding the actual context of creativity and technological invention. As Gomery (1994) concludes:

In the end we need to abandon the "great man" version of history. Walt was no genius, nor is Michael Eisner [the current CEO of the Disney company]. We are the fools if we ascribe all the actions and strategies of a company to one man or woman. The Disney company is simply another capitalist enterprise with a history best understood within the changing conditions of twentieth-century America. (p. 86)

\section{Myth \#2: Disney is a unique and different company.}

It is still difficult for many fans, as well as academics, to think of the Disney company as a profit-motivated corporation. The company is thought to be somehow different or special, not tainted with the attributes of other corporations and their moneygrubbing policies. Challenging this myth involves understanding Disney as a capitalist enterprise, as well as considering how the company compares to other transnational media companies.

While this type of analysis is not sufficient to thoroughly understand the meanings and impact of cultural products, political economic analysis is an indispensable point of departure for the study of the media, and especially the Disney enterprise. While some of the academic studies of Disney acknowledge the commercial character of the Disney phenomenon, unless the study is primarily oriented to a business audience, relatively little depth is provided to understand the extent of Disney's empire or its corporate strategies. Grover (1991) and Taylor (1987) offered detailed financial discussions of the transition period during the 1980s, however, their discussions were aimed mostly at the business community. Meanwhile, in film studies, Gomery (1994) and Lewis (1994) presented useful discussions of the corporate characteristics of the company through the early 1990s. In addition, Fjellman (1992) and Bryman (1995) firmly ground their studies of Walt Disney World with interesting and refreshing discussions of Disney, commodities and consumption. However, these are rare examples among a glut of analyses that overlook the business side of the Disney Universe. 
The Disney organization has always been a profit-motivated company, despite the attention that has been mostly direct towards individuals associated with the company (primarily Walt Disney) and its products. The company operated as a relatively small independent production company during the 1930s and 40s, but moved into television and themes parks during the 1950s. By the 1980s, the company had started to move beyond the Disney brand with a range of other products. The Walt Disney Company has evolved into a fully-integrated transnational media and entertainment conglomerate, with revenues over $\$ 25.4$ billion in 2000 garnered from a diversified array of investments and activities. It is important to understand that the corporation's primary goal is to generate income for its stockholders. One need only look at company literature to find clear and overt statements of its purpose. For instance, the company's website states clearly:

Disney's overriding objective is to create shareholder value by continuing to be the world's premier entertainment company from a creative, strategic and financial standpoint. ${ }^{12}$ [emphasis added]

Further elaboration is provided by CEO Michael Eisner, in a 1981 staff memo, cited in Masters (1981):

Success tends to make you forget what made you successful... We have no obligation to make art. We have no obligation to make a statement. To make money is our only objective.

While this point may seem obvious or simplistic, it is overemphasized because of the tendency by many to think of "Disney" as something sacred and special, and not as a commerical, profit-based endeavor. The Walt Disney Company is similar to other corporations in that it is organized to earn income for its stockholders. The company may add business lines or sell certain holdings over the years, managers may come and go, depending on their success in contributing to the company's income. However, the underlying motivation - the profit motive- endures.

Dissecting the Disney Empire. Often, people don't realize the scope of the Disney empire. Thus, to better understand the way that the Disney company operates as a profit-seeking corporation, a brief snapshot its holdings and activities at the beginning of

\footnotetext{
12 http://www.disney.com/Investor Relations.
} 
the 21st century is presented here, based on company reports and other sources. (This overview also will be relevant when we consider Myth \#3.)

Studio Entertainment. The Disney company includes a wide range of entertainment products, including animated and live-action films under the Walt Disney label, as well as the Touchstone, Hollywood, Miramax and Merchant-Ivory labels. Thus, the company distributes adult and foreign films that are not associated with the family-oriented, PGrated Disney brand. Adding Buena Vista and Miramax's revenues, the company received over $\$ 1.5$ billion, or nearly $22 \%$ of the market share in the US and Canadian markets in 1998.

Buena Vista Home Entertainment manages Disney's home video business and interactive products around the world. Disney also has diversified its television business similar to its film offerings, producing and distributing a variety of programming under the ABC, Buena Vista, Touchstone and Walt Disney labels.

Disney also produces theatrical versions of successful animated films and has become an undeniable presence in Manhattan, not only by way of its stage productions and the Disney Store in Times Square, but through extensive real estate holdings, including $\mathrm{ABC}$ 's headquarters.

Audio and musical products offer further opportunities to feature Disney properties, and are especially lucrative for animated features. Buena Vista Music Group now coordinates Disney's various recorded music businesses, which include Hollywood Records, Mammoth Records and Lyric Street Records, as well as a wide range of audio and music products.

Consumer Products. Disney's merchandising activities are legendary in terms of their historical precedence as well as more recent strategies. The Walt Disney Company is certainly the foremost merchandising company in Hollywood and produces or licenses a seemingly endless array of products. Disney merchandise is marketed at retail outlets around the world, as well as through its own outlets at the theme parks, through on-line sites, by way of the Disney Catalogue and at Disney Stores around the world. 
Internet and Direct Marketing. Disney OnLine creates and distributes content for online services, interactive software, interactive television, and Internet web sites. www.disney.com is consistently rated as one of the Web's most popular sites, while The Daily Blast serves as a subscriber-based web site which includes various features from Disney-owned enterprises.

A wide range of printed material also is produced by the Disney company, from comic books and children's magazines to adult-oriented magazines and books. At the end of 1998, the company claimed that their print products were published in 37 languages and distributed in more than 100 countries. The company claims to lead all other publishers in the world in the area of children's books and magazines, but the company also publishes under the Hyperion banner, which includes ESPN Books, Talk/ Miramax Book, ABC Daytime Press and Hperion East.

Theme Parks and Resorts. The Disney empire includes six major theme parks: Disneyland (including hotels, shopping, dining and entertainment venues and a new addition, California Adventure); Walt Disney World Destination Resort (including four different theme parks, numerous hotels, recreational activities and shopping outlets); Tokyo Disneyland (with Tokyo DisneySea, planned for 2001); and Disneyland Paris. The next location for a Disney theme park is Hong Kong.

The company also operates smaller, regional themed sites. DisneyQuests are indoor entertainment venues "combining the magic of Disney with interactive technologies and classic story-telling," as well as retail merchandise and food areas, while ESPN Zones feature sports-themed dining and entertainment. The Disney Cruise Line features voyages from the Florida complex to the Bahamas, with activities on board for adults and for families. The company also was the mastermind of Celebration, the neo-traditional planned community south of Disney World.

A number of sports properties supplement the company's strong sports media holdings (see below), including the Mighty Ducks (hockey), the Anaheim Angels (formerly, the California Angels baseball team), as well as a extensive sports facilities in Florida. 
Media Networks. Through the acquisition of ABC/Capital Cities in 1995, Disney firmly established its role as one of the dominant players in the US media industry. The $\mathrm{ABC}$ television network provides abundant opportunities to promote Disney-produced programming and other businesses, as well as exploiting ABC's more popular programs throughout the rest of the Disney empire.

In addition, Disney owns 10 television stations (affiliated with $\mathrm{ABC}$ ) reaching around $25 \%$ of the nation's households, as well as 42 radio stations reaching 13 million people weekly. Most of the Disney stations are affiliated with the ABC Radio Network, which boasted affiliations on 4,400 stations, reaching more than 147 million listeners weekly. ESPN Radio is broadcast 24 hours, with its flagship station ESPN Radio 1000 in Chicago. Radio Disney features special radio programming for children, and was received by 45 stations at the end of 1999 .

Disney's ownership of ESPN is through ABC, which owns $80 \%$ of ESPN Inc. in partnership with the Hearst Corporation. The franchise includes four domestic cable networks, regional syndication, 21 international networks, radio, Internet, retail, print and location-based dining and entertainment. At the end of 1999, the flagship network reached over 77 million subscribers domestically, while ESPN International has been claimed to reach more than 152 million households in 190 countries internationally. The ESPN franchise has recently diversified its activities even further, adding ESPN Magazine, ESPN Radio, ESPN Zones (the restaurant entertainment centers), ESPN Skybox on Disney Cruise Line ships, and ESPN merchandise. Meanwhile, ESPN.com is claimed to be the most popular sports site on the Internet.

Disney's other cable holdings include the Disney Channel, $37.5 \%$ of the A\&E Network, $37.5 \%$ of The History Channel, $50 \%$ of Lifetime Entertainment Services (including Lifetime and the Lifetime Movie Network), 39.6\% of E! Entertainment Television (including E!, is seen in more than 120 countries), "style" — a 24-hour network devoted to design, fashion and decorating), Toon Disney (with recycled Disney programming, and SoapNet (a 24-hour soap opera channel). 
Disney and the Media Oligopoly. It is clear that the Disney company today represents a dominant player in the media and entertainment business - a sector that, at least in the US, has become increasingly more concentrated over the last few decades, as corporations have moved or converged across industry lines to form diversified, transnational conglomerates. Several of these media giants look very much like Disney — The News Corp., AOL Time Warner Inc., and Viacom Inc. Other major corporations hold powerful media outlets, along with other lines of business - General Electric Co., Vivendi Universal (formerly, Seagrams), and Sony Corp.

According to a study at the end of 1998, only nine corporations owned the major US broadcast television networks, controlled the production and distribution of theatrical motion pictures, produced, co-produced or had financial interests in over $95 \%$ of primetime television programming, and owned or had financial interests in over $95 \%$ of the cable channels. (Kunz, 1998) Following this study, CBS was taken over by Viacom, thus eliminating one of the nine companies. Consequently, at the end of the 1990s, we are left with eight extremely large corporations forming an unprecedented media and entertainment oligopoly. While these companies may compete in some ways, they represent an incredible concentration of commercial control over the information and communication resources of the country. The Disney company must be seen and understood within the context of this media oligopoly, which some have called "The National Entertainment State." ${ }^{13}$

Even though political economists in communication and media have been drawing attention to these issues for several decades, there is still some reluctance to incorporate such analysis into the study of media, especially the analysis of Disney's cultural products.

\section{Myth \#3: Disney is only for kids.}

Since Disney is one of the world's leading brands associated with products for children, it is often assumed that the company and its products are mainly for kids.

\footnotetext{
${ }_{13}$ See the special report on "The National Entertainment State," in The Nation (June 1996). For further discussion of media concentration, see Herman and McChesney (1997), Bagdikian (1997), and Bogart (1995).
} 
However, the company profile above indicates that many of Disney's businesses are not aimed purely at children, or even families, thus less discussion of this myth is necessary. However, by combining political economic and audience analysis, as well as closer examination of products or texts produced by Disney, a clearer picture of the Disney audience emerges.

Despite the oft-cited emphasis on children, Disney's products cut across age groups in assorted ways. When we refer to "Disney," the association is ordinarily connected to those clearly labeled Disney products aimed at the "family" market. Nevertheless, the point is that targeting families means attempts to appeal to different age groups, not just children.

In the few academic studies of Disney audiences, exposure to Disney-branded products has been found to be typically strongest during childhood. However, even these products are enjoyed by adults. This is not surprising in that many Disney products have been designed with older audiences in mind, including many of the classic Disney films, but especially the theme parks and resorts. Indeed, the ratio of adults to children who visit the parks is estimated at 4:1. (Bryman, 1999)

Another example is Disney's Winnie the Pooh franchise, which the company acquired in the 1960 s. $^{14}$ As a Disney spokesman explained:

...Disney now has three distinct Pooh lines, each targeted at a different market. Each line is aimed at a distinct demographic and market, but even within a product line there's segmentation. Individuals and even groups tend to make a connection to particular characters. Eeyore, for example is most popular with teens, possibly because he is a little different from the others. But teens seem to be attracted to characters that are a little different. (Hirsch, 1999)

With over 100 companies producing Pooh products, plus the promotion of Pooh across the company's other business sectors, the Pooh characters have recently even started to outsell Mickey, Minnie and friends. As an industry trade journal reported:

\footnotetext{
${ }^{14}$ For an interesting discussion of the development of Disney's version of Winnie the Pooh, see Sparks, (1998).
} 
"Disney has done a magnificent job overall with Pooh, licensing and marketing products that appeal to a lot of different audiences and demographics." (Hirsch, 1999)

It is also important to recognize the many products and activities that Disney aims directly at adults, e.g. Touchstone, Hollywood and Miramax films, as well as ABC, ESPN, and other cable channels listed above. The company also has been especially active in hosting sporting events, such as marathons, auto races and an assortment of sports tournaments (golf, football, volleyball, as well as in-line skating and skate-boarding). The industry publication, Brandweek, explains: "Disney has started hosting events to try to appeal to everyone from empty nesters and senior citizens to honeymooners and postcollege singles." (Stanley, 1995, p. 18)

In summary, then, it seems easy to conclude that Disney is not only for kids. Indeed, to understand "Disney audiences," it is necessary to consider the wide range of products produced and distributed by the company, as well as the widespread availability and unique exposure to a range of Disney products at different periods of peoples' lives.

\section{Myth \#4: Disney products are wholesome and unbiased.}

Another myth is related to the content of Disney-branded products, which are assumed to be wholesome, safe, and pure, as well as ethical, virtuous and unprejudiced. Through various methods of textual analysis, many studies have identified reoccuring themes in Classic Disney products, especially those having to do with representation and ideology. Only a few examples need be discussed here to challenge this myth.

Most notable is Dorfman and Mattelart's (1975) classic analysis of Disney comics, which presented a Marxist critique drawing on semiotic and psychoanalytic approaches to identify a "Disney ideology," The authors skillfully dissected these texts, identifying various components of Disney ideology such as the representation of the Third World people ("noble savages"), the glorification of consumption, etc. Twenty-five years later, their wideranging critique is still right on target for many of these issues.

Other scholars have analyzed Disney products by focussing on the representation of women. While a feminist analysis of Disney products would seem to be elemental, there 
were relatively few examples before the last decade or so. One of the earliest studies was Stone (1975), who reviewed the heroines in stories by the Grimms brothers and the Disney versions, drawing on feminism, as well as the critique of the Disneyfication of children's literature. She observed that Grimms' heroines are relatively uninspiring, however, ". . . those of Walt Disney seem barely alive. In fact, two of them hardly manage to stay awake." Meanwhile, May (1981) criticized Disney's portrayal of women as stereotypically bad or good, as well as contrasting Disney's heroines with heroes. She concluded that heroes succeed, not because of how they look or what they wish for, but because of what they do. "The only tests of most heroines require nothing beyond what they are born with: a beautiful face, tiny feet, or a pleasing temperament. At least that is what we learn from the translations of the Grimm tales, and especially from Walt Disney."

Using content analysis, Hoerrner (1996) reviewed Disney films from Snow White to The Lion King, and found that women are portrayed as weak, pristine and incapable of independent action. The study found that males account for $57 \%$ of Disney characters, while females represent only $21 \%$. In addition male characters are far more aggressive, with $47 \%$ of their actions comprised of physical aggression.

Other analysts have pointed out that the themes emphasized in Disney culture are reminiscent of a past America and may have less to do with the reality of America today (see Wallace 1996 and Fjellman 1992). These studies have focussed on the theme parks, especially, where a Disney version of history (or "Distory") has been critiqued. .

Other discussions of Disney themes often are related to fantasy and imagination. Indeed, the role of pleasure is a natural and important element in human nature, as some media analysts have noted in recent work. While the inclination to seek pleasure and escape, and to look for utopian experiences is natural, the Disney brand of fantasy is a ready-made, highly promoted and powerfully seductive option, often assumed to be one of the few "acceptable" options available. However, the problem with Disney's version of fantasy, imagination and pleasure is the direct connection with a specific set of values. In other words, as Giroux (1999) and others have persuasively argued, Disney products are not necessarily "innocent" — whether one is considering the proliferation of Disney 
products in our consumer culture or the mainstream American values represented in Disney products.

It is clear from these studies and many others that Disney products include definite and often unmistakable themes and values, and are not always wholesome and unbiased or innocent. Most are neatly tied into a conservative vision of the world and linked directly with consumer culture. Indeed, some of these analyses point out that the legacy of Walt Disney and the Disney company itself have been especially adept at representing what America has represented: business, progress, individual initiative. It has incorporated the American personality, as fun-loving, innocent, optimistic, with a sense of fair play and what is right. In addition, the success of the Disney company has come to represent American ingenuity and cleverness.

The problem is that these attributes also form the basis of many American values that have either been mythologized or not necessarily even embraced by everyone. Indeed, Disney values also have been associated with All-American traits such as conservatism, homophobia, Manifest Destiny, ethnocentricity, cultural insensitivity, superficiality, lack of culture, etc. Disney did not create these attributes, but it is possible to argue that the Disney empire helps to perpetuate them. Are they the only company that does so? Of course not. But they do it very well and (at least for many) in an appealing, seductive, and enjoyable way.

\section{Myth \# 5: Disney is universally adored.}

The final myth to be considered briefly here is associated with the reception of Disney products. It is often assumed that Disney is somehow "universal" and beloved by people everywhere. It is not hard to believe that this is not the case, however, very little research has been done on Disney audiences. The following discussion is based on a few of these studies, but especially draws from the Global Disney Audience Project (GDAP), a recent study that analyzed Disney audiences in 18 different countries (see Wasko, Phillips and Meehan, 2001).

It is undeniable that Disney is recognized and known around the world. For instance, the GDAP study found that over 95\% of its respondents had seen a Disney film. 
The company and ardent fans would want us to believe that this is a natural phenomenon. In considering this claim, it might be instructive to cite one of Walt Disney's explanations:

Disney is a thing, an image in the public mind. Disney is something they think of as a kind of entertainment, a kind of family thing, and it's all wrapped up in the name Disney. ... You see, I'm not Disney any more. I used to be Disney, but now Disney is something we've built up in the public mind over the years. It stands for something, and you don't have to explain what it is to the public. They know what Disney is when they hear about our films or go to Disneyland. They know they're gonna get a certain quality, a certain kind of entertainment. And that's what Disney is. (quoted in Jackson, 1993, p 11)

This account reveals one of the keys to Disney's presumed universality: "...what we've built up in the public mind over the years." The Disney brand has been carefully nurtured and controlled, as well as globally marketed and promoted. Thus, if Mickey Mouse is assumed to live in the hearts and minds of people all over the world, then, it is because The Mouse and other Disney characters have been carefully manufactured and effectively distributed to reach the hearts and minds of people all over the world.

The Disney Company has grown and expanded globally by vigilantly controlling their products, characters and images, plus developing their reputation as a company and as a brand that produces positive, wholesome, family and children's entertainment. The Disney company takes advantage of its reputation by presenting the corporation as special and different. Again, its brand recognition has been built and zealously protected, allowing the company to expand into whatever new areas develop, drawing on their strong reputation.

The company has been built on a strong historical base, taking advantage of global trade opportunities that have expanded the empire far and wide, to the point where it is possible for company representatives and others to claim that Disney and Mickey Mouse are universal. But we also need to remember that this "universality" is not necessarily automatic or natural, but has been and continues to be deliberately manufactured and carefully controlled.

Furthermore, at least some audience research has shown that not everyone actually adores all things Disney. There are many ways that people respond to the Disney 
phenomenon, ranging from fascination to repulsion. (For a discussion of Disney audience archetypes, see Wasko, 2001.) From the few audience studies that have been done, it may be possible to conclude that responses to Disney are certainly not automatic and mechanical, nor universal or ubiquitous, but complex, somewhat diverse, and often contradictory.

Yet, one of the most amazing aspects of the Disney phenomenon identified by the GDAP study is the consistently uniform understandings of the essence of "Disney." There seems to be an almost universally-accepted awareness of what "Disney" means, as well as a recognition of the basic characteristics of the Classic Disney - even though people may differ as to whether or not they agree with or embrace these meanings or values, or to what extent they may engage in Disney experiences.

The GDAP results found that whether or not respondents liked Disney, they generally identified the core values represented in the company's products. Over 93\% of the respondents agreed that Disney promoted fun and fantasy, while over $88 \%$ agreed on happiness, magic and good over evil. Other terms that ranked very high (in the $80 \%$ range) were family, imagination, and love/romance. In other words, Disney represents a kind of symbolic ubiquity - the core values and ideas that it promotes are understand similarly everywhere.

But this may not be too surprising, either, as these characteristics are the ones that the Disney company consistently and emphatically insists upon in its own self-definition and in its incessant promotion and marketing. The company repeats endlessly that it is about "family", "magic", "happiness" and "fun." And, over and over, people refer to Disney as "family", "magic", "happiness" and "fun." People's similar understandings of Disney may suggest that there is relatively little room for active or alternative readings of texts, such as Disney's, which are carefully coded and controlled, and not polysemic and open.

In many of the national studies that were a part of the GDAP research, respondents were found to be engaging and negotiating Disney texts, but within the contexts of national cultures, ritualized use of media, as well as expectations and 
predispositions learned from Disney about Disney texts. The GDAP analysis suggests that some negotiation occurs, but that negotiation occurs within the intersection of the political economy of the mediated text, the national context within which that text plays economic as well as cultural roles, the cultural practices of a society and its social units (like families), and finally individual consciousness. This indicates that negotiation is quite diverse and often complex, requiring an interdisciplinary approach that integrates political economy, cultural studies, sociology, and anthropology. While each approach is crucial, no one approach is enough.

To summarize, this article has attempted to challenge a few of the myths about Walt Disney, the Disney company and its products. While the arguments have been somewhat abbreviated here, they rely on a wide range of research that has been done over the years on various aspects of the Disney phenomenon, thus exemplifying the value of integrating different theoretical approaches and methodologies. While many of the studies drawn upon for this analysis do not represent an integrated approach, this particular discussion attempts to build upon a political economic analysis with historical, cultural and audience research. Thus, in the process of challenging some of the Disney myths, another traditional myth (hopefully) has been dispelled. That is, the integration of different approaches and methods for the study of media and communication not only is possible, but at least is being attempted by some critical communication researchers.

\section{References:}

Bagdikian, Ben H. The media monopoly, 5th ed., Boston: Beacon Press, 1997.

Bell, Elizabeth, Haas, Lynda, and Sells, Laura (eds.). From mouse to mermaid: The politics of film, gender, and culture. Bloomington, Ind., Indiana University Press, 1995 .

"The Big Bad Wolf," Fortune (November 1934): 145-148.

Bogart, Leo. Commercial culture: The media system and the public interest. New York: Oxford University, 1995.

Bryman, Alan. Disney and his worlds. London: Routledge, 1995.

Bryman, Alan. "The Disneyization of society," The Sociological Review 47, no. 1 (1999): 25 . 
Eliot, Marc. Walt Disney, Hollywood's dark prince. New York: Birch Lane Press, 1993.

Fjellman, Steven. Vinyl leaves: Walt Disney World and America. Boulder, Colo.: Westview Press, 1992.

Giroux, Henry. The mouse that roared: Disney and the end of innocence. Lanham, Md.: Rowan \& Littlefield, 1999.

Gomery, Douglas, "Disney's business history: A reinterpretation," in Disney Discourse, ed. Eric Smoodin. 71-86. New York: Routledge, 1994.

Grafly, Dorothy. "America's youngest art." American Magazine of Art (July 1933): 337.

Greene, Katherine and Greene, Richard.The Man behind the magic: The story of Walt Disney, New York: Viking, 1991.

Grover, Ronald. The Disney Touch. Homewood, Ill.: Business One Irwin, 1991.

Hahn, Don. Animation magic: A behind-the-scenes look at how an animated film is made. New York: Disney Press, 1994.

Herman, Edward S. and McChesney, Robert W. The global media: The new missionaries of corporate capitalism, London: Cassell, 1997.

Hirsch, Jerry. "Winnie the Pooh gains momentum across Disney product lines." Knight-Ridder/Tribune Business News (4 January 1999).

Jackson, Kathy Merlock. Walt Disney: A bio-bibliography. Westport, Conn.: Greenwood Press, 1993.

Kunz, William. "A political economic analysis of ownership and regulation in the television and motion picture industries." Ph.D. dissertation, University of Oregon, 1998.

Lewis, Jon, "Disney after Disney: Family business and the business of family," in Disney Discourse: Producing the Magic Kingdom, ed. Eric Smoodin. 87-05. New York: Routledge, 1994.

Low, David. "Leonardo da Disney." New Republic (5 January 1942): 16-18.

Maltin, Leonard. The Disney films. New York: Crown, 1973.

Masters, Kim. The keys to the kingdom: How Michael Eisner lost his grip. New York: William Morrow \& Co., 2000.

May, Jill. "Walt Disney's interpretation of children's literature," Language Arts, 58, 4 (1981), pp. 463-72

McReynolds, William Irvin. "Walt Disney in the American Grain” Ph.D. dissertation, University of Minnesota, 1971).

Meehan, Eileen. "Critical Theorizing on Broadcast History," Journal of Broadcasting and Electronic Media 30, no. 4, (Fall 1986): 109-113.

Miller, Diane Daisy. The story of Walt Disney, New York: 1956. 
Mosco, Vincent. The political economy of communication: Rethinking and renewal, London: Sage, 1996.

Mosley, Leonard. Disney's world, Briarcliff, NY: Stein and Day, 1985.

Murdock, Graham. "Large Corporations and the Control of the Communications Industries," in Culture, Society and the Media, ed. Michael Gurevitch, Bennett, Tony, Curran, James and Woollacott, Janet. 118-150. London: Methuen, 1982.

"The National Entertainment State," The Nation, June 1996.

Peary, Danny Peary and Peary, Gerald.The American animated cartoon: A critical anthology, E.P. Dutton, 1980.

Schickel, Richard. The Disney version: The life, times, art and commerce of Walt Disney. New York: Simon \& Schuster, 1968.

Sparks, Colin. "From the Hundred Aker Wood to the Magic Kingdom," Professorial Lecture Series, University of Westminster, 14 October 1998.

Stanley, T. L. "Disney pitch: 'Not just Mickey Mouse'.” Brandweek (13 February 1995): 18.

Stillwell, Miriam, "The story behind Snow White's \$10,000,00o surprise party," Liberty (9 April 1938): 8-10.

Stone, Kay. "Things Walt Disney never told us." Journal of American Folklore, 88 (1975): 42-50.

Taylor, John. Storming the Magic Kingdom. New York: Knopf, 1987.

Taxel, Joel. "A Literature Review of the Impact of Walt Disney Productions Inc. on American Popular Culture and Children's Literature," in American Educational Research Association (1982).

Thomas, Bob. Walt Disney: An American original . New York: Simon \& Schuster, 1976.

Wasko, Janet. Understanding Disney: The manufacture of fantasy, Oxford: Polity Press, 2001.

Wasko, Janet, Phillips Mark, and Meehan, Eileen. Dazzled by Disney? The Global Disney Audience Project, London: University of Leicester Press, 2001.

Watts, Steven. The magic kingdom: Walt Disney and the American way of life, New York: Houghton Mifflin, 1997. 